\title{
Pathological effects of phaseolus vulgaris isolectins on pig jejunal mucosa in organ culture
}

\author{
M J L Kik, J F J G Koninkx, A van den Muysenberg, F Hendriksen
}

\begin{abstract}
The interaction of plant lectins with pig small intestinal epithelium in organ culture was studied. The binding of Phaseolus vulgaris (PHA) isolectins E4 and L4 to the microvilli and microvillus vesicles in the top area of the villi was shown by immunoelectron microscopy. Differences were observed in the distribution of the isolectins. In the explants cultured for five hours with the PHA isolectins, the enterocyte height and the villus length were decreased, and a lower villus: crypt ratio was calculated. Ultrastructurally, the microvilli were shorter and irregularly positioned. After incubation with both PHA E4 and PHA L4, clusters of small vesicles, tied off from the microvilli, were seen in higher numbers when compared with control explants. The activity of the brush border enzyme sucraseisomaltase was reduced in the PHA E4 incubated explants but did not change in the PHA L4 incubated explants. This investigation shows that explants of pig jejunal mucosa in organ culture are suitable for study of the pathological effects of lectins on the small intestinal mucosa. This method may also be used in elucidating the mechanisms by which damage to mucosal structure occurs.
\end{abstract}

The ubiquitous presence of lectins - for example seeds of legumes like pulses and beans - in plants eaten by man and his farm animals have been described in recent surveys. ${ }^{1-4}$

The biological activity of lectins can be abolished by proper heat treatment, although heat processing is not always very effective. ${ }^{5}$ Since most lectins are resistant to proteolytic breakdown in the gastrointestinal tract, they can reach the small intestine in a biological active form and bind to the glycoconjugates of the mucus and glycocalyx..$^{67}$ Pusztai et al ${ }^{89}$ suggest that many of these lectins may account for the morphological and functional changes in the epithelium of the small intestine leading to reduced efficiency of nutrient utilisation. Despite several studies, however, the pathogenesis of lectin induced changes in the intestinal tract has not fully been explained. ${ }^{10-12}$ In vitro studies show promising results in investigation of the effects of lectins on the small intestinal mucosa without any interference from the luminal contents and the intestinal micro flora. ${ }^{613}$ Moreover, the experimental conditions of the mucosal explants can be controlled more precisely than those in in vivo studies ${ }^{1+}$ and therefore may allow investigators to single out the direct effect of any given damaging agent on the mucosa. Another advantage of in vitro studies is the fact that only small amounts of deleterious material are needed. We chose explants of pig jejunal mucosa in organ culture, and therefore closely related to the situation in vivo, to study the interaction between Phaseolus vulgaris (PHA) isolectins E4 (4 erythroagglutinating subunits) and L4 (4 leucoagglutinating subunits) and the jejunal mucosa in vitro. We investigated the binding of PHA isolectins $\mathrm{E} 4$ and L4 to the explants and the subsequent lectin induced effects on morphology and brush border enzyme activity.

\section{Methods}

Approval for the experiments was given by the ethical and experimental committee of TNOCIVO, Zeist, The Netherlands.

Four 7 week old, male SPF pigs (CDI, Lelystad, The Netherlands) were premedicated with Stressnil and atropine and anaesthetised with fluothane and nitrous oxide in oxygen. The abdomen was opened and four jejunal segments $20 \mathrm{~cm}$ in length were taken $3 \mathrm{~m}$ proximal to the ileocaecal ligament. Explants were prepared according to Danielsen et al. ${ }^{15}$ The segments were cut open longitudinally at the mesenterial attachment and rinsed in Trowell's T8 medium at $21^{\circ} \mathrm{C} . .^{16}$ With a scalpel, the mucosa was separated from the subrmucosa and small explants $\left(9 \mathrm{~mm}^{2}\right)$ were cut from the mucosa. The explants were cultured according to the method described by Browning and Trier. ${ }^{17}$ Briefly, the culture conditions are as follows. Explants were placed on triangular cut stainless steel grids, the villus side facing upwards (six explants per grid), in sterile plastic organ culture dishes (Falcon 3037). To the central well of these dishes $0.9 \mathrm{ml}$ of Trowell's T8 medium was added, until a thin layer was drawn over the villous surface of the explants by capillary action. In the isolectin experiments, $50 \mu \mathrm{g}$ of the PHA E4 and PHA L4 isolectins respectively (E-Y Laboratories Inc, San Mateo, CA, USA) were added per $\mathrm{ml}$ of Trowell's T8 medium. The outer ring of the dish contained $3 \mathrm{ml}$ of bidistilled water. The dishes were placed in an airtight container, gassed with a mixture of $95 \% \mathrm{O}_{2}$ and $\mathrm{CO}_{2}$ for 15 minutes, ${ }^{17}$ and placed in an incubator $\left(37^{\circ} \mathrm{C}\right)$. Explants cultured for five hours in Trowell's T8 medium and explants cultured for five hours in Trowell's $\mathrm{T} 8$ medium in the presence of $50 \mu \mathrm{g}$ per $\mathrm{ml}$ of PHA E4 and L4 respectively, were processed for histomorphometric, electron microscopic, and biochemical examinations.

TISSUE PROCESSING FOR MORPHOMETRIC ANALYSIS

For morphometric analysis one explant from each dish was fixed in $0.1 \mathrm{mmol} / 1$ phosphate \\ 10 September 1991
}


buffered $4 \%$ formalin $\mathrm{pH} 7 \cdot 3$, dehydrated, and embedded in paraffin. Serial sections $(5 \mu \mathrm{m})$ were cut and stained with haematoxylin and eosin (HE). Using these sections, 10 well orientated villi and crypts were measured by means of a TEA Image Manager system (DIFA, Breda, The Netherlands). The villus height was represented by the distance from the crypt opening to the tip of the villus, and the crypt depth from the base of the crypt to the level of the crypt opening. The villus:crypt ratio was calculated to indicate the extent of morphological abnormality. The same sections were used to measure the enterocyte height from at least 25 epithelial cells with basalcentrally situated nuclei distributed randomly over the villi. Crypt enterocytes as well as enterocytes in the extrusion zone were excluded from these measurements.

\section{TISSUE PROCESSING FOR SCANNING ELECTRON MICROSCOPY}

One explant per dish was fixed in $2 \cdot 5 \%$ glutaraldehyde in $0.1 \mathrm{mmol} / 1$ cacodylate buffer $(\mathrm{pH}$ $7 \cdot 35 ; 440 ; \mathrm{mOsm}$ ) for 24 hours at $4^{\circ} \mathrm{C}$, and then rinsed in $0.1 \mathrm{mmol} / \mathrm{l}$ cacodylate buffer $(\mathrm{pH} 7 \cdot 35)$. The fixed explants subsequently were treated according to the OTOTO method (alternating osmium tetroxide and thiocarbohydrazide immersion), ${ }^{18}$ dehydrated through graded concentrations of ethanol, transferred to amylacetate, critical point dried with $\mathrm{CO}_{2}$, and mounted, villus side upwards, on aluminium stubs with silver paint. Specimens were examined using a Cambridge Camscan scanning electron microscope at $10 \mathrm{kV}$.

\section{TISSUE PROCESSING FOR TRANSMISSION ELECTRON} MICROSCOPY

One explant per dish was fixed in $0.1 \mathrm{mmol} / \mathrm{l}$ cacodylate buffered $2.5 \%$ glutaraldehyde $(\mathrm{pH}$ $7 \cdot 35,440 \mathrm{mOsm}$ ) for 24 hours at $4^{\circ} \mathrm{C}$, and subsequently rinsed in $0.1 \mathrm{mmol} / 1$ cacodylate buffer ( $\mathrm{pH} 7 \cdot 35)$. After postfixation with $1 \%$ $\mathrm{OsO}_{4}$ in $0 \cdot 1 \mathrm{mmol} / \mathrm{l}$ cacodylate buffer $(\mathrm{pH} 7 \cdot 35)$ for 16 hours at $4^{\circ} \mathrm{C}$, the explants were dehydrated in graded water-aceton mixtures and embedded in an EponAraldite mixture. Semi-thin sections were stained with toluidine blue. Ultra-thin sections were stained with uranylmagnesium acetate and leadcitrate and examined with a Philips EM410LS electron microscope at $60 \mathrm{kV}$.

\section{TISSUE PROCESSING FOR IMMUNOELECTRON MICROSCOPY}

One explant per dish was fixed in $2 \%$ paraformaldehyde and $0.5 \%$ glutaraldehyde in $0.1 \mathrm{mmol} / \mathrm{l}$ cacodylate buffer $\left(\mathrm{pH} \mathrm{7 \cdot 35)}\right.$ for seven days at $4^{\circ} \mathrm{C}$ and subsequently embedded in Lowicryl (polymerised at $20^{\circ} \mathrm{C}$ with $360 \mathrm{~nm}$ wavelength UV light). Ultra-thin sections were cut with a glass knife on a Reichert Ultracult E ultramicrotome and collected on uncoated 150 mesh copper grids. The primary antibodies used in this study were rabbit anti-PHA E4 and rabbit anti-PHA L4 (E-Y Laboratories Inc, San Mateo, CA, USA). Section labelling was performed by floating grids, sections down, on droplets placed on a strip of parafilm. All incubations were carried out at room temperature. The immunolabelling procedure is outlined as follows. Sections were incubated and pretreated on $20 \mu \mathrm{l}$ droplets of $1 \%$ bovine serum albumine (BSA) (Organon, Oss, The Netherlands) in $0.1 \mathrm{mmol} / 1$ phosphate buffered saline, $\mathrm{pH} 7 \cdot 4$ (1\% BSA/PBS) for 15 minutes. Excess buffer was removed with pieces of filtering paper before the grids were incubated on $20 \mu \mathrm{l}$ droplets consisting of antibody diluted in $1 \% \mathrm{BSA} / \mathrm{PBS}$ for 30 minutes. The final dilution of both primary antibodies was 1:160 with $1 \%$ BSA/PBS. After incubation the grids were washed three times for five minutes by floating, section down, on fresh $20 \mu$ l droplets of $1 \%$ BSA/PBS. Excess buffer was removed before incubation for 30 minutes with colloidal gold labelled secondary antibody. In this study goat anti-rabbit conjugated to $15 \mathrm{~nm}$ colloidal gold (EM grade) (Janssen Pharmaceutica, Berrse, Belgium) was used in a final dilution of $1: 20$. Before counterstaining with uranyl magnesium acetate and lead citrate, the grids were washed three times for five minutes with droplets of bidistilled water. Grids were air dried and examined with a Philips EM410LS electron microscope at $60 \mathrm{kV}$. Control sections were treated as above, omitting the primary antibody incubation step. ${ }^{19}$

\section{SUCRASE-ISOMALTASE ENZYME ACTIVITY ASSAY}

Three explants from each dish were frozen (liquid nitrogen) and stored at $-70^{\circ} \mathrm{C}$ before analysis. The explants were pooled (three explants for each time point or PHA concentration) in $2 \mathrm{ml}$ of $2 \mathrm{mmol} / 1$ TRIS- $50 \mathrm{mmol} / 1$ mannitol buffer (pH 7·1). From here all procedures were performed at $4^{\circ} \mathrm{C}$, unless mentioned otherwise.

The explants were sonified twice for 10 seconds in $1 \mathrm{ml}$ of bidistilled water. After sonification an aliquot of the suspension was used for protein determination. ${ }^{20}$ Sucraseisomaltase (EC 3.2.1.48) activity was determined according to Messer and Dahlqvist, ${ }^{21}$ using sucrose (Serva, Heidelberg, Germany) as substrate. The specific enzyme activity was calculated as $\mathrm{U} / \mathrm{g}$ of protein and expressed as the mean relative specific enzyme activity (SEM).

\section{STATISTICAL ANALYSIS}

The statistical significance of differences between means was analysed using the paired Student's $t$ test. In the Tables the values are expressed as percentages of the corresponding control values.

\section{Results}

MORPHOLOGIC CHARACTERISTICS OF PIG JEJUNAL EXPLANTS

The histology of the control explants and PHA E4 cultured explants are shown in Figure 1A and $B$ respectively. The results of the morphometric analysis of pig jejunal explants from PHA E4 and PHA L4 incubated and control explants are summarised in Table I. The morphology of the 

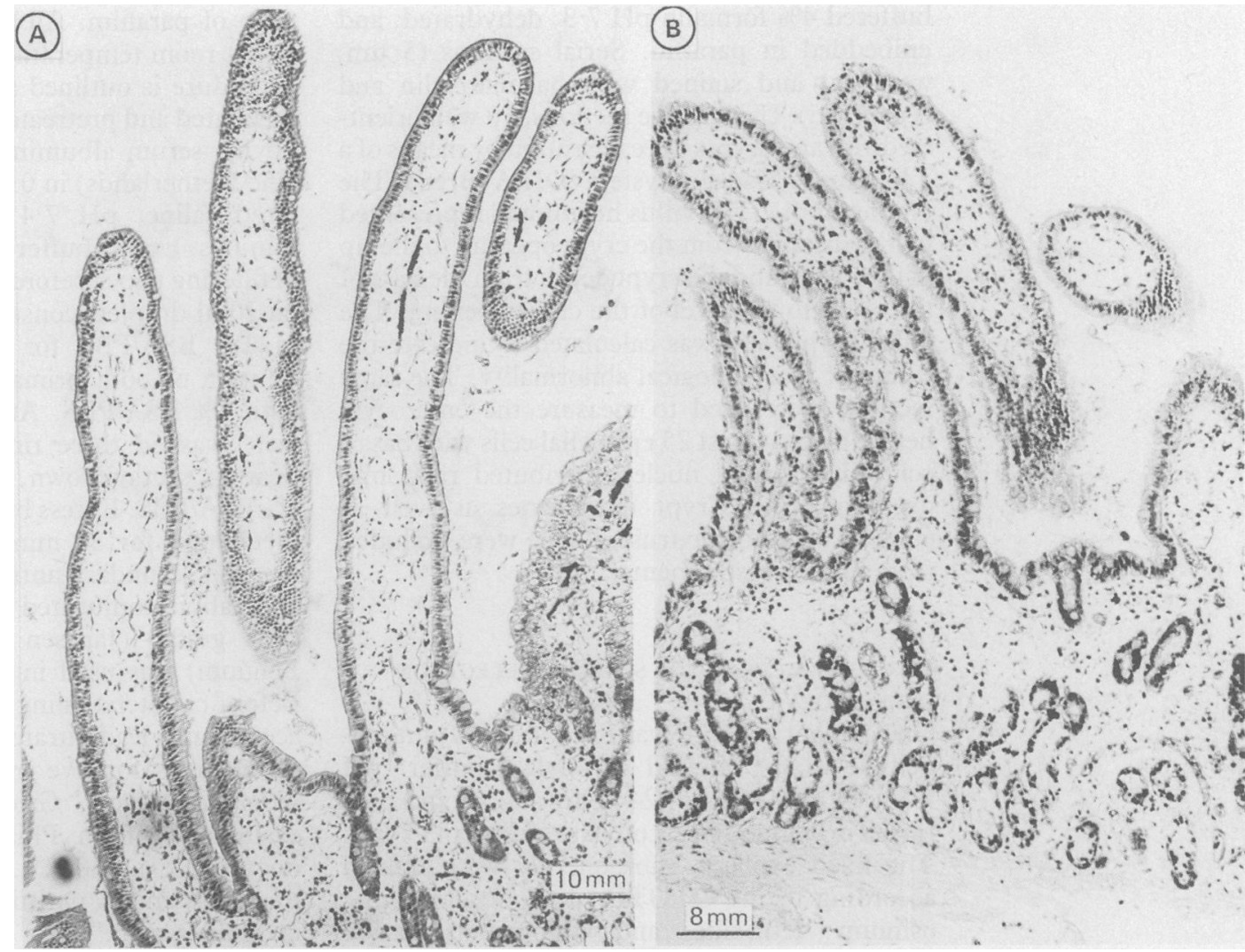

Figure 1: Effects of Phaseolus vulgaris isolectin E4 (PHA E4) on pig mucosal explants in organ culture (A). Control explant cultured for five hours in Trowell's T8 medium (B). Explant cultured in Trowell's T8 supplemented with $50 \mu \mathrm{g}$ of PHA E4/ml. The depth of the crypts remains unchanged.

control explants, cultured for five hours in Trowell's T8 medium looked normal by light microscopy. In explants cultured in PHA isolectins $\mathrm{E} 4$ and $\mathrm{L} 4$ there was a considerable reduction in the villus:crypt ratio. (Incubation of the explants with the isolectins resulted in reductions of $30 \cdot 1 \%$ for PHA E4 and $36 \cdot 7 \%$ for PHA L4.) As shown in Table I, the PHA induced reduction in the villus:crypt ratio of the explants was due to a change in the villus length only, whereas the PHA L4 induced decrease was accomplished by both a decrease of the villus length and an increase of the crypt depth. After incubation of the explants for five hours with PHA isolectin E4, the mean enterocyte height decreased by $18 \cdot 4 \%$, whereas incubation with PHA isolectin L4 resulted in a decrease of $10.6 \%$. Each of these reductions were statistically significant $(\mathrm{p}<0 \cdot 01)$.

ULTRASTRUCTURAL CHANGES IN THE EXPLANTS AFTER INCUBATION WITH PHA ISOLECTINS

The scanning electron microscopic studies

TABLE I Effects of Phaseolus vulgaris (PHA) isolectins on the length of villi, the depth of crypts, the villus:crypt ratio, and the height of enterocytes in pig jejunal explants (Values mean $(S E M))$

\begin{tabular}{lllllll}
\hline Explants & Villus & Crypt & $\begin{array}{l}\text { Villus:crypt } \\
\text { ratio }\end{array}$ & No & Enterocytes & No \\
\hline Control & $100 \cdot 0(2 \cdot 9)$ & $100 \cdot 0(2 \cdot 5)$ & $100 \cdot 0(9 \cdot 9)$ & 70 & $100 \cdot 0(1 \cdot 3)$ & 278 \\
PHA E4 & $70 \cdot 5(5 \cdot 5)^{\star}$ & $101 \cdot 0(6 \cdot 8)$ & $69 \cdot 9(5 \cdot 9)^{\star}$ & 70 & $81 \cdot 6(1 \cdot 6)^{\star}$ & 278 \\
Control & $100 \cdot 0(2 \cdot 7)$ & $100 \cdot 0(2 \cdot 9)$ & $100 \cdot 0(5 \cdot 0)$ & 30 & $100 \cdot 0(2 \cdot 5)$ & 115 \\
PHA L4 & $74 \cdot 4(1 \cdot 7)^{\star}$ & $114 \cdot 6(5 \cdot 4)$ & $63 \cdot 3(2 \cdot 5)^{\star}$ & 30 & $89 \cdot 4(1 \cdot 4)^{\star}$ & 115 \\
\hline
\end{tabular}

${ }^{\star} \mathrm{p}<0.01$ compared with control. showed that culturing explants for five hours in Trowell's T8 medium did not influence the morphology of villi and microvilli (Figs $2 \mathrm{~A}$ and B). However, as shown in Figure $3 \mathrm{~A}$ to $\mathrm{D}$, exposure of the explants to $50 \mu \mathrm{g} / \mathrm{ml}$ of PHA E4 and PHA L4 respectively, resulted in changes in the morphology of the villi and microvilli. In the PHA E4 cultured explants a pock pitted villi surface and fusion of microvilli were seen (Figs $3 \mathrm{~A}$ and B). The villi of the PHA L4 cultured explants were covered with dots of material (Figs 3C and D), which on cross section seemed to be derived from the microvilli.

The transmission electron microscopic study of control explants cultured in Trowell's T8 medium, showed microvilli that were even in
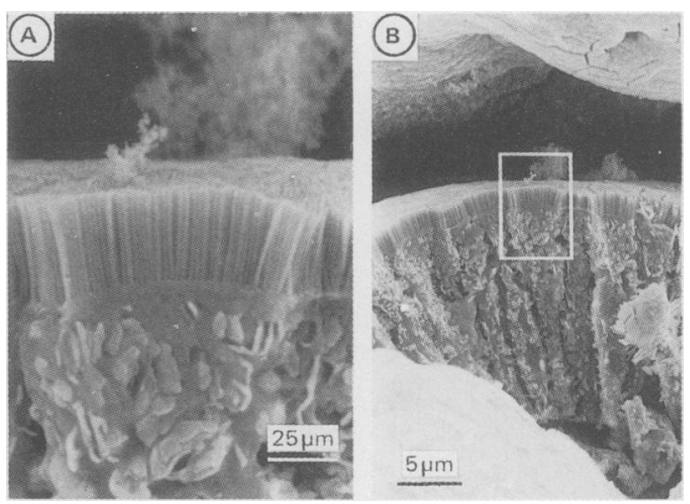

Figure 2: Scanning electron micrograph of a pig mucosal explant cultured in Trowell's T8 medium $(A)$. The microvilli are 


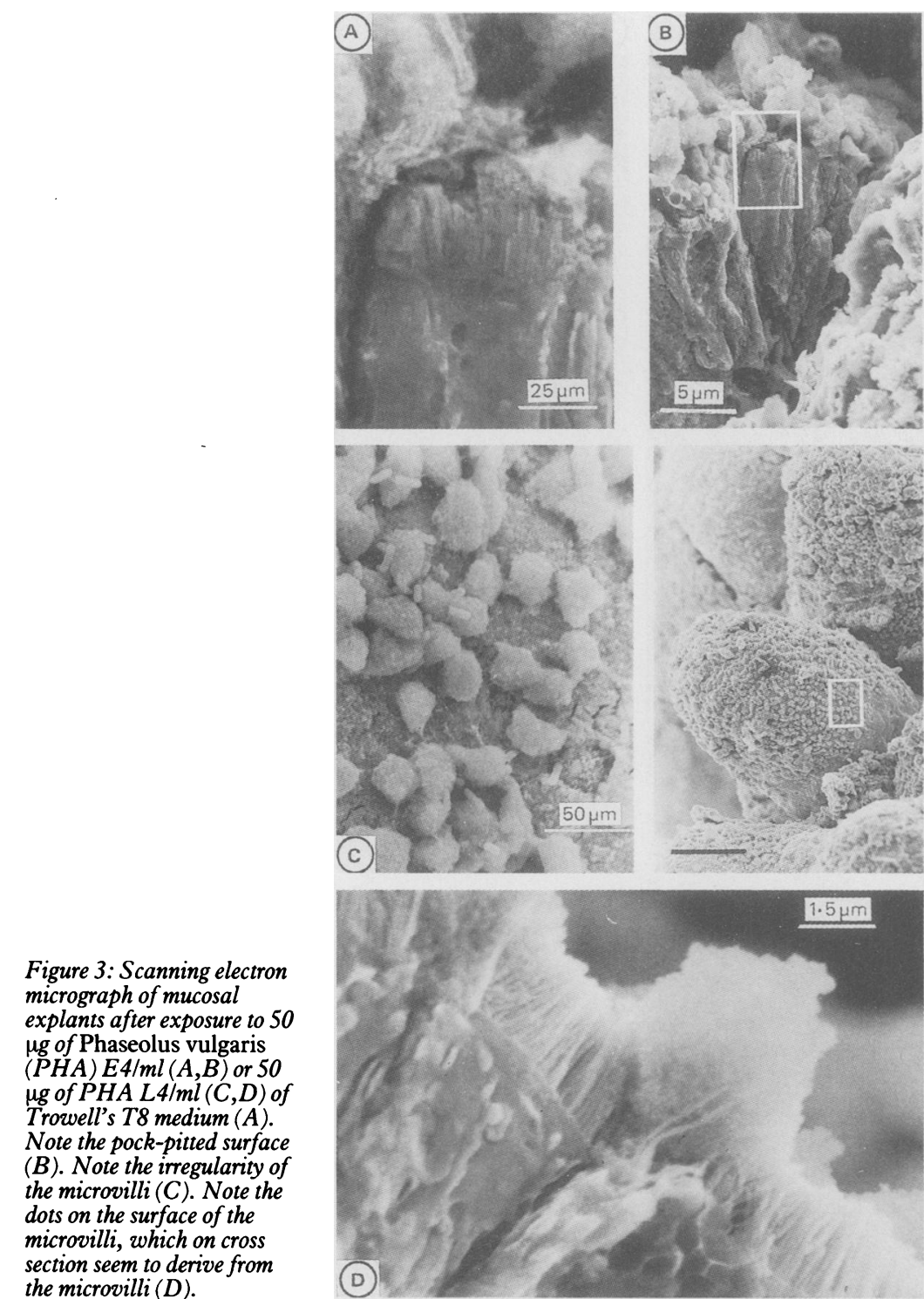

length and regularly positioned (Figs $4 \mathrm{~A}$ and 5A). The core of the microvilli, consisting of bundled actin filaments, was clearly seen to protrude into the cytoplasm. No vesicles seemed to be tied off from the microvillar tops. However, explants cultured in PHA E4 (Figs 4B and 5B) and PHA L4 (Fig 4C) clearly showed shortening of the microvilli of enterocytes on the upper third of the villi. They were irregularly positioned and fusion of microvilli frequently occurred. In addition, vast numbers of microvillus vesicles had been tied off and areas could be observed where a complete loss of microvilli had taken place. The described changes, however, seem less abundant in the PHA L4 treated explants compared with the PHA E4 treated ones.

BINDING OF PHA E4 and L4 TO PIG JEJUNAL EXPLANTS

As seen by immunoelectron microscopy PHA E4 (Fig 6A) and PHA L4 (Fig 6B) bind to the microvilli of the cultured explants. No differences could be detected with regard to the distribution of gold particles. The gold particles were located almost exclusively over the micro- villi and over the tied off microvillus vesicles. Staining was more evident in the top third of the villi but gold particles were also detected over the microvilli, along the length of the villi, and over the mucous contents of goblet cells, but not in the crypts. No gold particles could be detected in control explants.

EFFECT OF PHA ISOLECTINS ON THE BRUSH BORDER ENZYME ACTIVITY

The effect of PHA E4 and L4 on the specific activity of the brush border enzyme sucraseisomaltase in pig jejunal explants is shown in Table II.

Incubation of the explants in PHA E4 $50 \mu \mathrm{g} /$ $\mathrm{ml}$ resulted in a significant decrease of the relative specific activity compared with control explants cultured in Trowell's T8 medium (Table II). PHA L4 at a concentration of $50 \mu \mathrm{g} /$ $\mathrm{ml}$ did not influence the relative specific activity of sucrase-isomaltase.

\section{Discussion}

The objective of this study was to investigate whether organ culture from pig small intestinal mucosal explants represents a suitable model for studying the harmful effects of PHA isolectins E4 and L4 on enterocyte morphology and function. If so, this model may be used to examine the mechanisms of damage to small intestinal mucosal structure.

When small intestinal mucosal explants are cultured for up to five hours in Trowell's T8 medium, only minor changes occur in the histological as well as ultrastructural architecture (Figs 1A, 2, 4A, and 5A). In addition, other investigators have reported, based on light and electron microscopic criteria, that the mucosal morphology of pig small intestinal explants is well preserved during organ culture. ${ }^{16}$ The minor changes in the mucosal morphology that take place during culture are presumably caused by the in vitro environment. ${ }^{22}$

Exposure of the pig jejunal explants to PHA E4 and PHA L4 for five hours provokes numerous morphological changes (Table I, Figs 1B, 3 $4 B$ and $C$, and $5 B$ ). These changes include a significant reduction in mean enterocyte height, a decrease in the villus:crypt ratio because of the reduced villus length and increased crypt depth in PHA L4 treated explants, and the presence of shortened and irregularly positioned microvilli with vast numbers of tied off microvillus vesicles. Furthermore, in the PHA E4 treated explants the specific activity of the brush border membrane enzyme sucrase-isomaltase was decreased significantly (Table II). No significant difference could be detected in the PHA L4 treated explants.

By electron microscope immunocytochemistry, immunogold localisation of PHA E4 and PHA L4 was shown over the glycocalyx of the intestinal microvilli, the microvillus vesicles in the top one third area of the villi (Fig 6), and somewhat less over the microvilli of enterocytes in the lower parts of the villi. ${ }^{33}$ No differences were observed between the distribution of the isolectins on the cells, which is in agreement with 

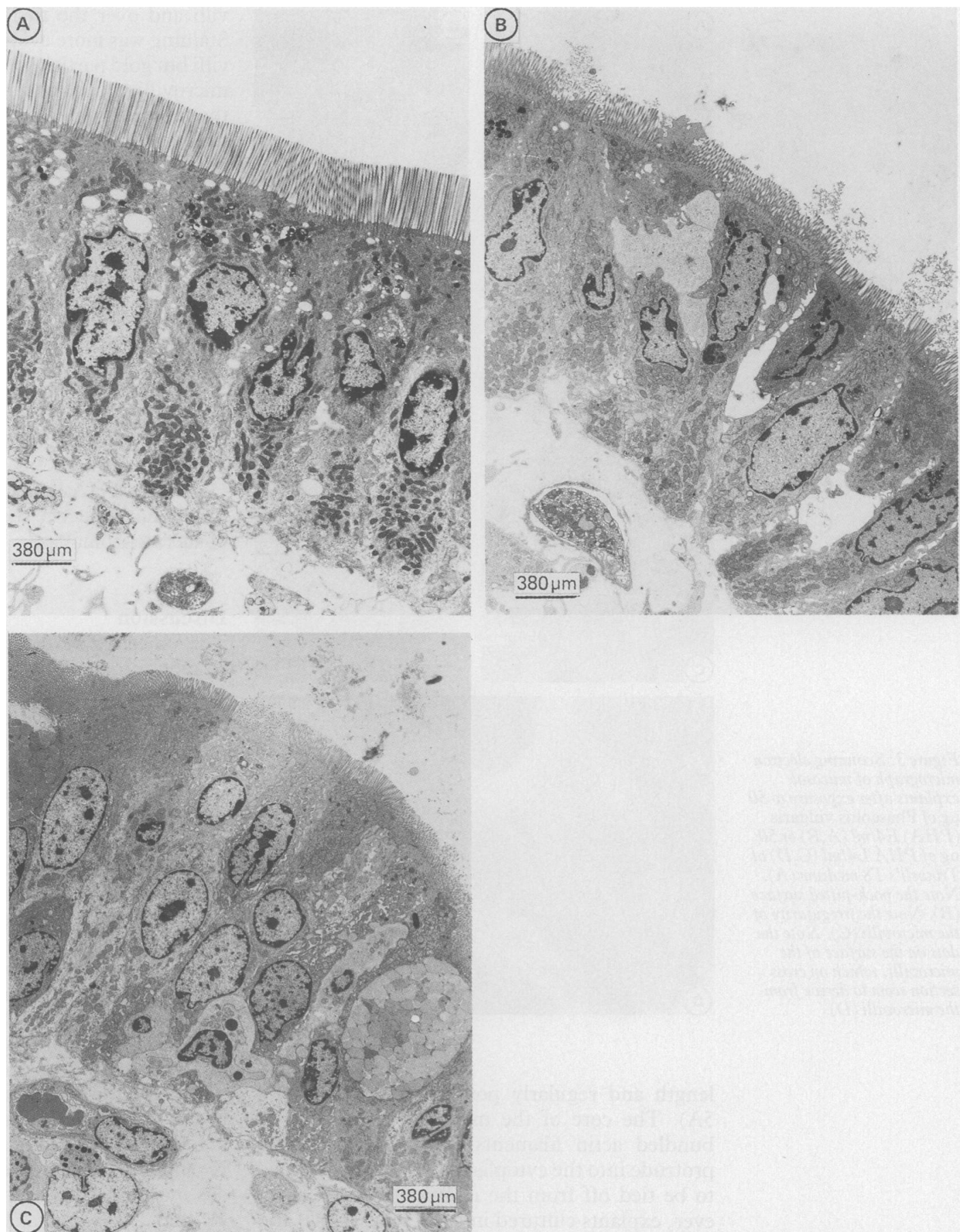

Figure 4: The absorptive epithelium from pig mucosal explants cultured for five hours in Trowell's $T 8$ medium $(A)$, in the presence of $50 \mathrm{\mu g}$ of Phaseolus vulgaris $(P H A) E 4 / \mathrm{ml}(B)$, and PHA L4/ml (C) of Trowell's T8 medium (A). The epithelium appears normal $(B)$. Note the masses of microvillus vesicles $(C)$. Same but less abundant.

the findings of King $e t a^{24}$ in rats fed raw kidney bean protein.

Extensive changes in small intestinal enterocytes, decrease in villus length, irregularity of microvilli, clusters of vesicles associated with the brush border, and complete loss of microvilli are described in rats after intraluminal administration of concanavalin A or wheat germ agglutinin. ${ }^{1 "}$ When rats (conventional as well as germ free) were fed purified PHA and adherence of PHA to the brush border membrane was obvious, none of these morphological changes of the small intestinal mucosa could be observed. ${ }^{6}$ However, rats fed a diet containing crude PHA beans display an extensive disruption and abnormal structure of microvilli in the small intestine..$^{1025}$

Our findings clearly show that exposure of pig mucosal explants to PHA E4 or L4 for five

TABLE II Effect of Phaseolus vulgaris (PHA) isolectins on the specific activity of the brush border enzyme sucraseisomaltase in pig jejunal explants (values, mean (SEM))

\begin{tabular}{lcc}
\hline & $\begin{array}{l}\text { Activity of sucrase-isomaltase } \\
\text { (U/g protein) }\end{array}$ & No \\
\hline Control & $100 \cdot 0(5 \cdot 2)$ & 56 \\
PHA E4 & $82 \cdot 9(11 \cdot 4)^{\star}$ & 56 \\
Control & $100 \cdot 0(2 \cdot 2)$ & 24 \\
PHA L4 & $98 \cdot 7(9 \cdot 9)$ & 24 \\
\hline
\end{tabular}

${ }^{\star} \mathrm{p}<0.01$ compared with controls 


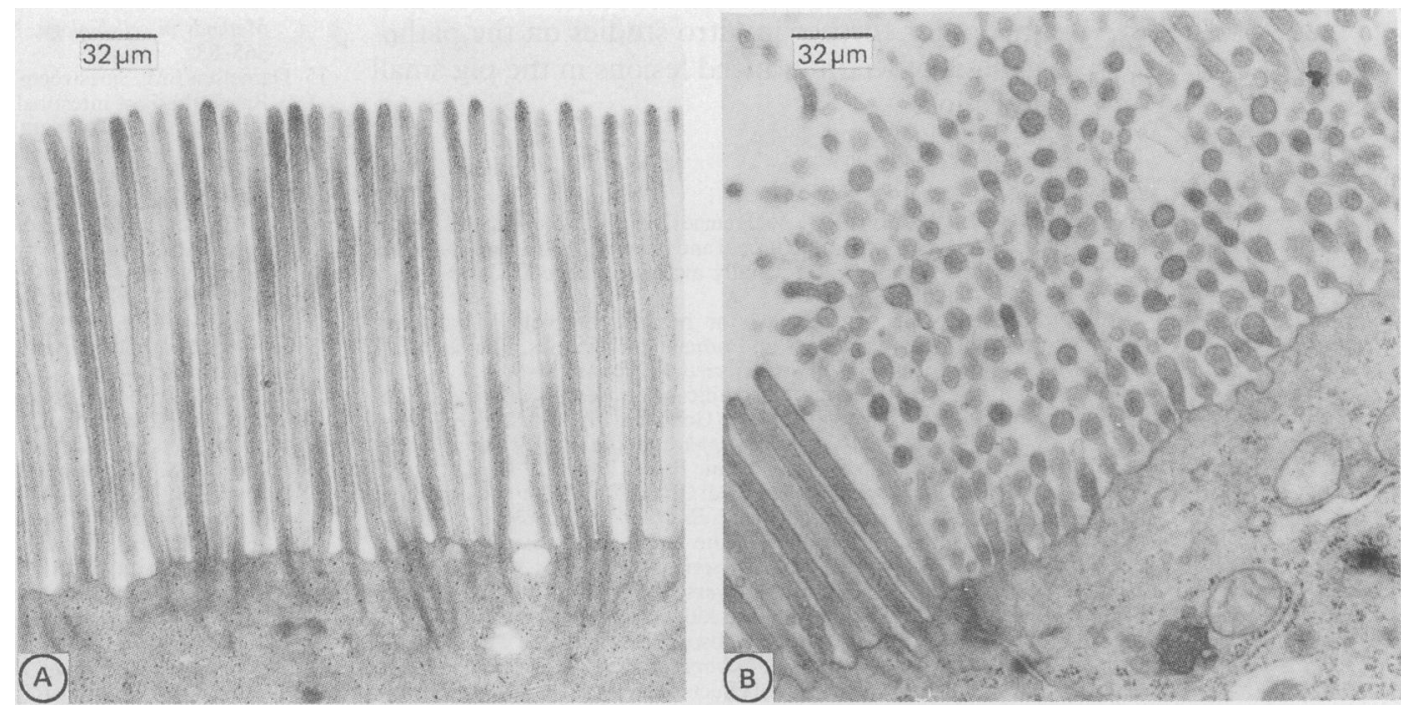

Figure 5: The microvilli of the absorptive epithelium from pig mucosal explants cultured for five hours in Trowell's T8 medium: $(A)$ in the presence of $50 \mu \mathrm{g}$ of Phaseolus vulgaris $(P H A) E 4 / \mathrm{ml}(B)$ and $50 \mu \mathrm{g}$ of PHA L4/ml of Trowell's T8 medium. (A) The microvilli are even in length, and regularly positioned. The fibrillary roots clearly protrude into the cytoplasm. $(B) T h e$ microvilli are irregularly positioned and shortened, microvillous vesicles are tied off. The microvilli are fragmentary.

hours results in binding of the isolectins to the intestinal epithelium, brush border membrane changes, and diminished villus length; and in case of PHA E4 incubated explants, a decreased activity of sucrase-isomaltase.

Several mechanisms such as the globular (G):filamentous (F)-actin ratio, the cell actin content, the cytoskeletal protein turnover or the pool size of actin binding proteins, or both, might be involved in the regulation of the intestinal brush border villus length. ${ }^{26}$ In differentiated human colon carcinoma Caco-2 cells exposed to soybean agglutinin we have shown that the shortening of the microvillus length is accomplished only by a rapid shift in the G:Factin ratio. ${ }^{27}$ After binding of the PHA isolectins to the brush border membrane of the enterocytes, this mechanism (changes in the actin cytoskeleton of the cell) probably plays a role in the pathogenesis of microvillus abnormalities.
After exposure of rat intestinal epithelium to intraluminal dietary lectins clusters of vesicles associated with the brush border can be found..$^{128} \mathrm{Also}$, in organ culture, blebbing and vesiculation of microvilli leading to increased numbers of vesicles nearby the brush borders of PHA isolectins incubated explants were observed (Fig 5). The presence of these vesicles might reflect an increased turnover of microvillus membrane.

The loss of brush border membranes interferes at once with the activity of brush border membrane associated enzymes. Our results show a correlation between the amount of microvillus vesicles that have been tied off and the decrease in activity of sucrase-isomaltase (Table II).

The similarity between the lectin induced lesions in vivo ${ }^{11} 28$ and in vitro responses of pig mucosal explants clearly shows that organ culture of pig mucosal explants represents a suitable
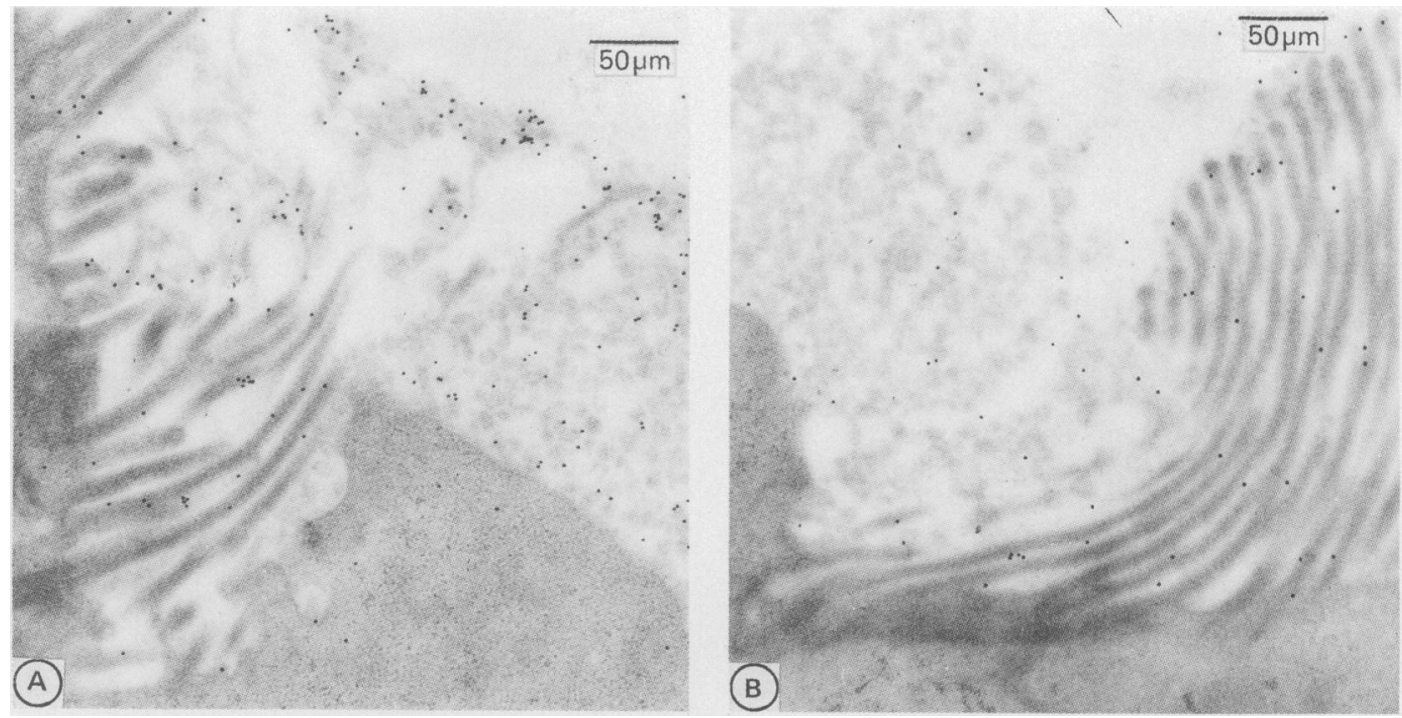

Figure 6: Immunogold localisation of Phaseolus vulgaris (PHA) E4 (A) and PHA L4 (B) in the brush border and apical cytoplasm of an absorptive enterocyte in a pig mucosal explant. Gold particles are almost exclusively located over the microvilli in the top area of the villi and tied off vesicles. No differences could be detected between the isolectins with respect to the localisation of their binding. 
model for further in vitro studies on the pathogenesis of lectin induced lesions in the pig small intestine.

1 Grant G, More LJ, McKenzie NH, Stewart JC, Pusztai A. A survey of the nutritional and haemagglutination propertie of legume seeds generally available in the UK. Br $\mathcal{F} \mathrm{Nutr}$ 1983; 50: 204-14

2 Liener IE. Significance for humans of biologically active factors in soybeans and other food legumes. Joumal of the American Oil Chemists' Society 1979; 56: 121-9.

3 Liener IE. Nutritional significance of lectins in the diet. In: Liener IE, Sharon N, Goldstein IJ, eds. The lectins. Properties, functions and applications in biology and medicine. Properties, functions and applications in biology and

4 Noah ND, Bender AE, Reaidi GB, Gilbert RJ. Food poisoning from raw red kidney bean. $B M \mathcal{Y}$ 1980; 281: $236-7$.

5 Pusztai A. Constraints on the nutritional utilization of plant proteins. Nutr Abstr Rev (series B) 1985; 55: 363-9.

6 Banwell JG, Boldt DH, Meyers J, Weber FL Jr. Phytohemag glutinin derived from red kidney bean (Phaseolus vulgaris) a cause for intestinal malabsorption associated with bacteria overgrowth in the rat. Gastroenterology $1983 ; 84: 506-15$.

7 Pusztai A. The biological effects of lectins in the diet of animals and man. In: Bog-Hansen TC, van Driessche, eds Lectins, biology, biochemistry, clinical biochemistry. Berlin: Walter de Gruyter, 1986: 179-94.

8 Pusztai A, Clark M, King TP. The nutritional toxicity of Phaseolus vulgaris lectins. Proc Nutr Soc 1979; 38: 115-20.

9 Pusztai A. Plant lectins. Biological function. Acta Biochim Biophys Hung 1987; 22: 355-75.

10 King TP, Pusztai A, Clarke EMW. Kidney bean (Phaseolus vulgaris) induced lesions in rat small intestine: 1 . Light microscope studies. F Comp Pathol 1980; 90: 585-95.

11 Lorenzsonn V, Olsen WA. In vivo responses of rat intestina epithelium to intraluminal dietary lectins. Gastroenterology 1982; 82: 838-48.

12 Sjolander A, Magnusson KE, Latkovic S. Morphological changes of rat small intestine after short-term exposure to Concanavalin A or wheat germ agglutinin. Cell Struct Fumct 1986; 11: 285-93.

13 Wilson AB, King TP, Clarke EMW, Pusztai A. Kidney bean (Phaseolus vulgaris) lectin-induced lesions in rat small (Phaseolus vulgaris) lectin-induced lesions in rat small
intestine: 2. Microbiological studies. F Comp Pathol 1980; 90: $597-602$.

14 Trier JS. Organ culture of the mucosa of human small intestine. In: Curtis HC, Trump BF, Stoner GD, eds
Methods in cell biology. New York: Academic Press, 1980: 365-83.

15 Danielsen EM Sjoestroem $\mathrm{H}$, Noren $\mathrm{O}$, Bro B, Dabelsteen $\mathrm{E}$. Biosynthesis of intestinal microvillar proteins. CharacterisaBiosynthesis of intestinal microvillar proteins. Characterisation of intestinal explants in organ culture and evidence for the existence of pro-forms of the microvillar enzymes. Biochem f 1982; 202: 647-54

16 Trowell OA. The culture of mature organs in a synthetic medium. Exp Cell Res 1959; 16: 118-47.

17 Browning TH, Trier JS. Organ culture of mucosal biopsies of human small intestine. $\mathcal{F}$ Clin Invest 1969; 48: 1423-32.

18 Malick LE, Wilson RB. Modified thiocarbohydrazide procedure for scanning electron microscoy: routine use for normal, pathological and experimental tissues. Stain Technol 1975; 50: 265-9.

19 Roth J. The colloidal gold marker system for light and electron microscopic cytochemistry. In: Bullock GR, Petrusz P, eds. Techniques in immunocytochemistry. London: Academic Press, 1983:217-84.

20 Lowry OH, Rosebrough NJ, Farr AL, Randall RJ. Protein measurement with the folin-phenol reagent. 7 Biol Chem 1951: 193: 265-75.

21 Messer M, Dahlqvist A. A one step ultramicromethod for the assay of intestinal disaccharidases. Anal Biochem 1966; 14: 376-92.

22 Howdle PD, Corazza GR, Bullen AW, Losowsky MS. Gluten sensitivity of the small intestinal mucosa in vitro: quantitative assessment of histologic changes. Gastroenterology 1981, 80: 442-50.

23 King TP, Begbie R, Cadenhead A. Nutritional toxicity of raw kidney beans in pigs. Immunocytochemical and cytopathological studies on the gut and the pancreas. $\mathcal{F}$ Sci Food Agric 1983; 34: 1404-12.

24 King TP, Pusztai A, Grant G, Slater D. Immunogold localisation of ingested kidney bean (Phaseolus vulgaris) lectins in epithelial cells of the rat small intestine. Histochem $\mathcal{F} 1986$ 18: $413-20$.

25 Weinman MD, Allan CH, Trier JS, Hagen SJ. Repair of microvilli in the rat small intestine after damage with lectins contained in the red kidney bean. Gastroenterology 1989; 97 1193-204.

26 Stidwill RP, Burgess DR. Regulation of intestinal brush border microvillus length during development by the $\mathrm{G}-$ to F- ratio. Dev Biol 1986; 114: 381-8.

27 Draaijer M, Koninkx J, Hendriks H, Kik M, van Dijk J Mouwen M. Actin cytoskeletal lesions in differentiated Mouwen $M$. Actin cytoskeletal lesions in differentiated human colon carcinoma Caco-2 cells after

28 King TP, Pusztai A, Clarke EMW. Kidney bean (Phaseolus vulgaris) lectin-induced lesions in rat small intestine. 3. Ultrastructural studies. F Comp Pathol 1982; 42: 357-73. 